\title{
Governance And Its Impact On Textile Companies
}

\author{
Ma. de Lourdes Elena Garcia Vargas \\ Magda Gabriela Sanchez Trujillo
}

Universidad Autónoma del Estado de Hidalgo

doi: 10.19044/esj.2016.v12n16p195 URL:http://dx.doi.org/10.19044/esj.2016.v12n16p195

\begin{abstract}
From an economic perspective, the flaws and weaknesses of the government seem to be more evident because of situations such as vagueness of the boundaries between governments and public policies that make it harder work in an attempt to regulate activities of companies to generate small effective numbers and productive trade relations.

To know the situation in the textile sector a diagnostic was carried out in 17 companies in production, technological development areas and university services, with an exploratory and quantitative study, and transeccional design. Afterwards were given a qualitative perspective with action research design when applying interviews with government representatives, and advisory councils, chambers of commerce to establish their participation in finding solutions in relations to the problems observed: distrust of the business sector programs offered by the government, minimal participation in training and innovation forums in Consultation Councils and in the decision-making process which prevent the sector increase its development.
\end{abstract}

Keywords: Governance, public policies, business relationships

\section{Introduction}

The problems of this century and the need to solve them demand that international, national and local institutions be able to organize themselves and coordinate and create agreements evolving into more representative systems (Lynn, Heinrich and Hill, 2001). This is how the local and state governments gain importance as a representative form of the governance used to describe the changes arising at this level, waiting for the dissolution of the central power with the inclusion of private figures in the programs characteristic of municipalities, where the community tends to become responsible for identifying and solving diverse economic, social and educational problems. The importance of the local development is on harnessing the resources and endogenous capacities of the municipality and 
determine how the public authorities, the private sector and civil society perceive them. From this approach, new horizons are opened where the local public action has a growing involvement of non-governmental actors in the decision-making process.

Governments should take advantage of the resources and capabilities and point out how the public authorities, the private sector and civil society see them; unifying and permeating the term "governance" as the process of governing that symbolizes a set of actions that are executed when a company is run and it also includes the action of civil society and the private sector.

Patrick Le Gales (2002) considers the term "governance" as a series of policy tools to plan, manage and control established relationships with new arguments and techniques, with new information practices that provide elements for creating and maintaining networks that connect the actors, regulatory and performance indicators in meeting established goals, that is to say, governance is considered as a tool in solving social problems. Examples of this are the legislative instruments and regulatory frameworks that give rise to the idea of a protector, guarding state, the economic and fiscal instruments to promote the strengthening of a redistributive state and the creators of incentives that promote a state that gives mobility to society.

The term governance according to Bevir \& Rhodes (2006), includes society as a whole and the state as an articulator; their proposal is in relation to the construction of agents and defined actors who will generate ideas and provide solutions to public problems, and officials who are guided by values and creative actions.

It means that the government has ceased to be a part of a hierarchical, demanding, authoritarian state to become a facilitator state (Hall \& Taylor, 1996) which, when connected to the various areas, must provide a vision capable of promoting growth, opportunities for the inhabitants, providing them with the tools and means to be able to transform their own context, improve their living conditions, attract and support the establishment of businesses with a shared commitment, socially responsible, who will encourage sustainable and sustained development by promoting coresponsibility with the companies. These firms are regarded as institutions or organizations dedicated to activities that will try to fulfill the needs of their clients for goods or services, that will yield good economic or welfare results, and which are managed in financial environments that will ensure success (Miwa \& Ramseyer, 2000).

\section{Literature review}

Kumar \& Maiti (2007) express that government policies in some countries become less friendly to inefficient companies, these public policies 
can be comprised at different levels, from the municipal to the national level, and may even extend their influence to international contexts.

In conducting the study in Mexico, of the federal, state and local governments and their relationship with society to achieve development, productivity and innovation, it is important to consider the government's actions from the need to interact with all stakeholders, such as the civil society and the private sector.

The Federal Government acts as the administrator of programs for institutions to implement and enforce the national goals set in the 2013-2018 National Development Plan with five guiding principles: I Mexico in Peace. II Inclusive Mexico. III Mexico with Quality Education. IV Prosperous Mexico. V. Mexico with Global Responsibility (Official Gazette, 2013). One of the institutions that offers programs that contribute to the fulfillment of the goals outlined for science technology and innovation is the National Council of Science and Technology (CONACYT), specifically with the Innovation Incentives Program (PEI) which aims to encourage business investment in activities and projects related to research, technological development and innovation in order to boost economic competitiveness in the country.

The Government of the State of Hidalgo, through the 2011-2016 State Development Plan, in its section V entitled Modern, Efficient and Municipal Government (Democracy and Social Participation) provides a strategic objective to strengthen the transition from an electoral to a participatory democracy which will improve governance conditions within a framework of civic responsibility to impact the state development taking advantage of associations with political, social and economic actors from the state, the region and the municipality, in order to promote an institutional framework for citizen observation, seizing the participatory potential of society in the pursuit of making sound decisions

The Local Government of Tepeji del Rio, Hidalgo, in its 2012-2016 development plan, paragraph four. Peace and social tranquility, coexistence in harmony (Democracy and the rule of law), shares the strategic goal of the state government towards participatory democracy, co-responsible in the design, implementation and evaluation of public policies, in the monitoring of the government administration and its impact on municipal development.

Each of the plans shows the involvement of the different levels of government, proposing a scheme that tries to include society as a whole in problem solving and decision making. But, how are governments and society involved in promoting the development of the textile industry and resolving the problems identified in the areas of production, technological development and university services in the Tepeji-Tula region? What are the short-term aspects that hinder the development of the textile industry in the Tepeji-Tula region? A general analysis of textile enterprises, of their needs 
and problems, the textile industry in the state of Hidalgo and specifically in the Tepeji-Tula region is performed next, in addition it explains how the government is involved in solving these problems and establishing the set of circumstances that hamper its development.

\section{Textile enterprises}

Textile companies represent a sector according to their skills, behaviors, the characteristics of their knowledge base, experience and learning processes, innovative interactions; their innovation activities should be a series of social constructs, organized with systems and rules designed to provide resources, mostly intangibles, to coordinate their actions (Coriat \& Weinstein, 2004) they must apply clean production technologies, be environmentally aware companies, industries with sustainable industrial development.

According to the National Chamber of the Clothing Industry, the textile industry in Mexico has a presence in most states. It was one of the most important generators of employment, (Feldman, 2009); in Mexico City excelled with $12.3 \%$ in the State of Mexico with $11.5 \%$ and in the state of Hidalgo, 3.8\%.These results are not encouraging because as Cardenas (2007) commented in the thread-textile-clothing chain in the US market, this was an important sector in terms of employment, export orientation and achievements of the regulatory framework resulting from the Free Trade Agreement (NAFTA) since the mid-nineties.

\section{Overview of textile companies}

The situation of enterprises in the Mexican textile industry in the states of Aguascalientes, Mexico City, State of Mexico, Guanajuato, Hidalgo, Jalisco, Puebla and Tlaxcala in 2004 and 2005, according to the Center for the Study of Competitiveness Institute of Technology Mexico (CEC-ITAM, 2010) indicate that $64.8 \%$ of the textile companies started operations less than 30 years ago, 93.3\% is independent and only $97.1 \%$ works with national funds. 39\% of these produce spinning, 58.1\% weaving, $59 \%$ finishing and $63.8 \%$ manufactures finished textile products. They also report that $44.8 \%$ on the surveyed companies sold their products mainly in the region. 26.5\% have computerized machinery for spinning, 36.9\% for weaving and $15.7 \%$ for fabric dyeing. The main innovations were in the design, variation and finishing of the textile products manufactured, the acquisition of machinery and equipment, improved management practices, quality and customer service. The strength of the industries is focused in the product and offering the client good service; its weaknesses have to do with the difficulties textile companies face when they try to get credits (they are 
not considered as creditworthy) and the obsolete machinery some companies have.

\section{Problems of textile companies}

At present the textile industry is in deep crisis, even though it has a geographical advantage to reduce transportation costs, delivery and exporting times and the experience of exporting to the United States, Mexico generally has been displaced by the People's Republic of China (PRC) as the main chain supplier since 2002. This trend is not expected to change, while Mexico and Central America lose presence constantly since then. Mexico’s specialization and weakness in designing clothing and the massive imports in the textile segment contrast with the situation of PRC, as its exports have diversified into all segments of the series, which reflects important strengths in the production required for dressmaking. Competition between Mexico and the PRC for dressmaking is alarming, while the latter has the ability to produce its own supplies, Mexico and Central America need to import them from the USA (Garcia \& Sanchez, 2015).

Another important aspect is the one described by Ramirez (2011) when he stated that the problem in the development of the textile industry lays in the price of the inputs and declared that fiber increased its cost by $134 \%$.

Pedro Alonso explained in an article written for the newspaper Milenio (2013) that the textile sector in Mexico suffers from some problems arising from the free trade agreement and commented on the closing of maquiladoras (assembly plants): "In the 19 years since the signing of NAFTA, one thousand two hundred maquiladoras have disappeared in Mexico. In 1994 when the Treaty came into force between Mexico, the United States and Canada, there were a total of 2,000 maquiladoras, but in 2013 there were 800 left, most of which are family workshops or micro enterprises, engaged in dressmaking," he said one of the problems is the unfair competition from products entering the country, and the representative of the Maquileros Union attributed as the main negative factor the entering of Asian products; the businessman said in an interview that "the golden age was in the nineties with the maquiladoras as the main source of employment generation. "

Recent data shows that in Mexico, the value of exporting inputs, finishing, and textile products surpassed 70.2 million dollars according to statistics from INEGI [National Statistics and Geography Institute ] (2013) with investments for over 90.8 million dollars in the last fourteen years. Mexico sums exports for more than 6 billion dollars annually, making the country the fifth largest supplier of clothing worldwide and the first Latin America country for the United States. 
However, according to data from INEGI (2014) the performance to March was as follows: The hours of actual work were less for about $0.42 \%$ during the third month of 2014 compared with the month before, and the real average wages paid decreased by $0.41 \%$.In the analysis by economic activity, according to the 2007 Industry Classification System of North America, it fell $3.7 \%$ in the subsectors of textile inputs, manufacturing, and finishing of textiles (INEGI, 2014).The real average wages paid in the month of reference recorded a drop of $0.2 \%$ in relation to those of March 2013. This result came out from a drop of $2.2 \%$ in the salaries paid to workmen and a decrease in the wages paid to employees of $2.5 \%$, and in social benefits of one percent. The subsectors that showed a decline in real wages per person employed were the textile inputs and finishing of textiles (-) $2.2 \%$, basically, it pointed out that the textile industry has declined in a major way, mainly affecting production and therefore the workers of this industry, even their average earnings paid are down by $2.2 \%$ (INEGI, 2014) representing a problem, so the points of the textile industry which present these losses must be identified and diagnosed and how the different sectors of government and society act to reduce those problems.

The quality and development of communication channels for the transfer of textile products are affected by structural features such as the type and specificity of knowledge that the national production structure demands and the clarity of these demands, the inability in absorption of the scientific and industrial sectors, the failures in commercial activities that prevail in the knowledge market (UE, 2001), the lack of continuity and adaptability capacity of the policies in science and technology, the degree of connection with innovation, its role in the country's productive, scientific and technology development and its inaccuracy to raise innovative proposals for the development of areas of knowledge (Casalet, 2005).

There is also another big problem, the unfair competition that the selling of clothes from dubious origin, called "pirate", represents. In the last 12 years it has resulted in the fall in 60 percent of the textile industry in the state of Hidalgo, affecting the livelihood of more than two thousand 500 families. Another aspect that has contributed to aggravate the situation is the importing of clothes, which causes wages in the industry to be precarious since it is estimated that for a workday of more than eight hours, an employee perceives a little more than 100 pesos a day which causes job losses in the region; some of the shops that had 20 employees five or six years ago, are now down to 10. A particular element that affects the textile industry is dishonesty because the Mexican businessman is pressured more every time to offer better services while, at the same time, clothing that comes across from the USA usually does not even pay taxes, therefore it is cheaper for the customer (Acevedo, 2014). In addition to the above, textile 
entrepreneurs pay high prices for services in general, and as a result, some of the shops around the region have resorted to work in an almost artisanal manner instead of acquiring high technology equipment because of a lack of monetary resources (Acevedo, 2014).

\section{Needs of textile companies}

Strategic planning for the location of a company requires of an analysis of the internal and external environment, taking into account the mission, vision, and objectives of the businesses, as well as the social stability and social, economic, and sustainable development in order to make the most out of expenses, improve the quality of life of the people in a particular region by creating jobs, incorporating new processes as well as caring for and protecting the environment, promoting a culture of industrial ecology in line with the country's development so that it can be ecosustainable.

In a consumer environment in which the customer has become selective and demanding, due to the large number of suppliers in the market, it is necessary that companies in general and companies in the textile industry in particular seek to make themselves different in terms of the quality of the products offered to the customer and/or consumer, Romano \& Vinelli (2001).

Textile companies operate in an environment of uncertainty with the challenge of meeting their customers' requirements: having the right product in the right amounts, in time, keeping the costs of their operation at appropriate levels, etc., so that they can ensure business profitability. A great synchronization is required in the consumption and handling of raw materials by the textile companies and in the utilization of industrial waste. Therefore, it is necessary that to the exterior, they conform a symbiotic network with other companies that will allow them to use -in an integral manner- the waste of some as resources for others, thus the saving of materials and energy is beneficial in three aspects: economic, environmental and social. These aspects far from been considered as high investment costs, result in savings that will allow the optimization of their processes, efficiency in the use of their resources, and consequently, higher levels of productivity and profitability in the medium and long term accompanied by the transfer of knowledge and technology (defined as cooperatives interactions of information, comprehension and technical understanding that two or more organizations have established to transfer their know-how ${ }^{3}$ ), technical, scientific and/or technology knowledge of an organizational configuration to another (Stezano, 2007). The notion of transfer involves three types of channels to diffuse technology and/or knowledge: formal, informal and commercialization. The informal channel includes the personal interactions 
established without the intervention formal organization relations (Dahl \& Pedersen, 2003). The formal channel involves the transmission of knowledge (i) encoded by formal means such as publications, reports and conferences; and (ii) tacit via human beings, such as formal organizational arrangements for staff mobility and training of the workforce (Arvanitis, S., Kubli, U. \& Wörter, M. (2005). Finally, the marketing channel refers to exchanges based on scientific activities commercially oriented on specific processes or products: science-based companies, research contracts, consultancies, patents, licenses (Perkmann \& Walsh, 2008).

\section{The textile industry in Hidalgo}

The state of Hidalgo stands out in exports of inputs and finishing of textiles, with $13.3 \%$; in clothing $1.9 \%$ of the total percentage of the country. The cities of Tulancingo, Tula, the Otomi-Tepehua area, Tepeji del Rio and Zacualtipan excel in the textile industry, design and manufacture. This sector is one of the most important in Hidalgo, during the period 2003-2012 the sub-sector textile manufacturing inputs and finishing of textiles recorded an annual average growth of $1.3 \%$, above the national rate of $0.7 \%$ and rates of neighboring states with the exception of Veracruz, which recorded a rate of $3.0 \%$. On the other hand, in the subsector clothing manufacturing, Hidalgo presented an annual rate of $-1.9 \%$; negative rates were also observed in neighboring states except Tlaxcala which recorded a $0.9 \%$ rate (INEGI, 2014).

The strategic importance of the sector in the state is because it is one of the main generators of employment, and $75 \%$ of the municipalities have companies related to the textile and clothing industry. According to INEGI (2009) the municipalities with higher levels of production inputs and finished textiles, textile products and clothing were Tepeji del Rio, Tizayuca, Tlaxcoapan, Zapotlan, Tlanalapa, Tepeapulco, Pachuca, Mineral de la Reforma, Progress, Actopan, Cuautepec and Tulancingo, most of them are in Tepeji-Tula region. The census gross added value of the textile and clothing industry in the state accounted for $5.7 \%$ of the national total in 2008, which allowed Hidalgo to occupy the fifth place among the 32 Mexican states (INEGI, 2013). According to records of the Ministry of Economic Development in the period 2011-2013 there have been investments in these industries for 94.0 million pesos (SEDECO, 2014).

\section{Methodology}

A diagnostic study was carried out in 17 companies of the textile sector in the Tula-Tepeji region. 
The state of the art of the government development plan is revised and the points where support for the companies is possible are identified.

Scope of research. Exploratory and descriptive study to know the variables in a region is explored on its incidence in a population sample (Hernández, et al. 2014 p. 155).

Research Focus. The research approach is quantitative and later for a more complete view used a qualitative approach. The quantitative approach aims to focus the information is sequential and allows test the hypothesis, using data collection based on the numerical measurement and statistical analysis (Hernández, et al. 2014 p.10). The research design is transeccional as data is collected at a single time (Hernández, et al. 2014 p.154).

The qualitative approach has an action research design as it focuses on the diagnosis of problems in textile companies in Tepeji Tula region, allows identify the causes and consequences of the problem and generate possible solutions (Hernández, et al. 2014 p. 471). It focuses on providing information to guide decision making through interviews with representatives of Chambers of Commerce of Tula- Tepeji region and directors of programs that are sponsored by local and state economic development.

Variables. Technological development, productivity and university services. The variables give options to answer yes or no, and to detail the response if it is affirmative to recognize the physical condition of the plant, the flow of their processes, production control, inventory control, maintenance and technical assistance, the competitiveness of the products, processes and/or services, technological patrimony, technology management, information technology, quality, continuous improvement, applied research, links with local or nearby universities and the kind of support it receives from them for an analysis of their problems.

Sample. Nonprobability or directed. The study considered 17 textile companies in Tepeji Tula region.

Measuring instrument. It is structured in two parts: the first consists of general and identification data of the company (sector, address, year of establishment). The second part include 76 items focused on technological development, production, and university services.

\section{Results}

Being governance a proposed guide for transforming the binomial State-society (Bevir \& Rhodes, 2006) or the trinomial composed by the state, civil society and the private sector, it is possible to analyze textile companies in the Tepeji-Tula region in three specific aspects, such as production, technological development and university services, the government 
collaboration to solve these problems as well as circumstantial points from the government-society point of view and the results are presented below.

\section{Production}

The $90 \%$ of the economic units report a process manual, in $80 \%$ of them, the staff is aware of those manuals, 90\% have a person responsible for production planning, $70 \%$ carries out their production according to their purchase orders, and $30 \%$ based on an estimated demand; $100 \%$ report a production program, $80 \%$ accept that there is at least one production control mechanism to evaluate deviations between the program and the results, 50\% say they have bottlenecks in their production.

Based on the above, the State Government encourages the consolidation of companies with programs and services that meet their needs through counseling, training, technology transfer and access to finance, seeking their productive and competitive improvement and their permanence in the market. Thus, the productive framework for both, companies already established and entrepreneurs, is reinforced.

\section{Technological development}

This section covers products, processes or service competitiveness, as well as technology management, information technology, quality, quality control and quality assurance. With regard to the technological patrimony, $90 \%$ of the companies have some control on intellectual protection of patents and trademarks even if it is only a few of them who patent their products, only $20 \%$ believe it necessary to obtain advice, $30 \%$ admit to having a person responsible for technology management, $70 \%$ document the technological skills of their staff and 30\% have implemented technology in their product or production process.

a) Technology management. During their activities only $40 \%$ of these companies carry out part of the process or assembly outside their plant, $60 \%$ have established modernization or upgrading programs for their equipment, the same percentage reports keeping a permanent study to improve their processing, 90\% takes corrective technical measures (not preventive) to reduce costs and increase production, and $70 \%$ of these companies believe it is convenient to seek some professional advice (but they do not request it from nearby universities).

b) Competitiveness of products, processes or services. $50 \%$ of these businesses has at least one technological development project, the same number of companies reports conducting technological development research, but only $70 \%$ is prepared to meet with their development goals and describe enough technical resources for the development of new products. On the other hand, $100 \%$ analyze the information from claims and 
complaints as a feedback for the development of their products, also $60 \%$ of them perform technological benchmarking studies of their products, services and/or processes.

c) Information technology. It is important to have a network inside the company since it offers multiple benefits such as good communication among the different areas, which in turn results in quick solutions when solving problems. This study identified that $90 \%$ of these businesses have a network domain, however, only $40 \%$ use e-commerce; they do not exploit this resource to the maximum when it could represent additional benefits. Moreover $70 \%$ works with an administrative system known as Enterprise Resource Planning (ERP) and detailed policies for the implementation of their data, $80 \%$ use an automated system for routine work.

d) Quality. The quality of the products manufactured by any company makes a difference between what the customer will buy or not, making this a vital element. $100 \%$ of the companies have a quality department and quality agreements among their suppliers, but most of them have not reached certification. $40 \%$ had received complaints for poor attention to their customers, the latest being less than 30 days prior to the study; to avoid this situation and improve their product quality, the raw materials are checked by 70\% of companies in each delivery.

e) Quality Control. Another important factor for improving the quality of the textile products is to carry out a proper quality control. $90 \%$ of these enterprises decide on the characteristics or standard of quality of the finished product based on a statistical or sampling control; their measuring equipment has calibration and verification programs, in addition they claim that their products have an acceptable range for their customers.

f) Quality assurance. 70\% of companies have a system of quality assurance and continuous improvement, 30\% require of support for the implementation of a new system of quality assurance and a department for conducting applied research as well.

At this point the government takes actions such as the arrival of strategic investments and offering consulting services specializing in research and innovation for companies in the sector, contributing to the modernization of their production processes and reducing the risks of negative impact in their national and international competitiveness.

For a proper growth of the metalworking, logistics, textile and clothing, mining, and trade sectors, the government promotes the development of information and communication technologies and the implementation of technologies with low impact on the environment that will boost productivity, innovation and sustainability of business and likely will lead Hidalgo towards a knowledge society and a green economy. 


\section{University Services}

The link between universities as knowledge-generating bodies and the business sector allows graduates the opportunity to acquire a job in addition to a professional career development with a good performance. Only $40 \%$ of the companies know of any projects or research from universities in the region that could be of interest for them.

To perform the analysis of consistency between development plans and provide the state of Hidalgo with a range of strategies and actions to support the business sector, Universidad Autonoma del Estado de Hidalgo (UAEH) works together with researchers, managers and teachers of the University, experts on topics such as competitiveness, sustainable economic development, the environment, public administration, among others.

UAEH offers its expertise in applied and basic research as well as its innovation capacities in a participatory exercise with concrete proposals for action to assist in the development of the state in a realistic, ideal, close to the people manner and through which the state, the society, the economy will be enriched.

Finally, the University joins the state development through integrated actions in a tactical, dynamic six-year program, which generates specific innovative strategies to ensure social benefits. UAEH contributes specifically in the textile and technology sector by offering B. A. degrees related to the textile sector, with the largest number of employed professionals (2011-2017 Institutional Development Plan).

The result of interviews with the directors of programs sponsored by the state and municipal development programs considers vital the following points where work is been done:

1. Successful government policies related to the economic, social and environmental development are strengthened, exploiting the potential of a participatory citizenship in order to broaden the basis of legitimacy of the government actions.

2. Advantage is taken of the link among the different political, social, and economic actors, state, regional or municipal, to promote and institutional structure where citizens oversee the management of municipal organizations.

3. The participative potential of society is acknowledged with the intention of strengthen the democratic practices in all areas of public life.

4. Mechanisms are established that will bring closer social organizations and the government to coordinate, prioritize and meet the demands within a framework of transparency, viability and social impact.

In interviews with representatives of chambers of commerce and citizen advisory councils, we can sense that there is a closeness between 
society and the textile companies, but at the end, there are not agreements or actions due to the distrust generated by public organizations.

It is clear that some of the municipal initiatives were taken from the National Development Plan, category Mexico Prospero (2015) and are mentioned below:

1. Support to entrepreneurs and industrial parks in dealings with ecology and the environment, urban development, economic development. 2. Microcredits program for small businesses. 3. Promotion of employment in this sector (job pool with registered companies, supported by the National Employment Service through the 5th District in Tula; scholarships and work visas). 4. A system for the rapid opening of companies that issues plates and permits to operate. 5. Municipal Business Center. 6. Business forums in conjunction with the state and federal governments. 7. Support to the Citizens Advisory Councils offered in the city of Tula. 8. Consultation with the local Chamber of Commerce. 9. Collaboration of municipal council members and decision making. 10. Links with the university sector.

It is established that despite some progress, the dysfunctions and problems related to the needs of their environment, the application of research, links with the education sector, and others still persist.

\section{Conclusion}

There are differences, difficult to overcome but not impossible, in regard to the needs and problems expressed by the companies and the position of the local government. The state and society must work together in an orderly and participative manner with a shared responsibility in order to increase the development, productivity and innovation of textile companies in Tepeji del Rio recognizing the environment presented here. The educational institutions should promote and expand the scientific, social, humanistic and technological research to promote the generation and dissemination of knowledge to help promote social responsibility, preservation and protection of resources, of the environment and a sustainable, competitive and technological development with social responsibility in Hidalgo in communion with the local government.

A study on governance in the terms of environment and sustainable and sustained development in textile companies and the symbiotic relationship to care for and protect the aquifers by reducing the water footprint as well as the environment where these enterprises perform is recommended.

\section{References:}

Acevedo, G. (2014). Revivirá industria textil con Centro de Innovación. Milenio Hidalgo. 4 de enero 2014. Obtenido de 
http://www.milenio.com/hidalgo/Revivira-industria-Centro-NacionalInnovacion_0_220777981.html

Alonso, P. (2013). Cierran 1,200 maquiladoras en 19 años de Libre Comercio. Milenio México. 13 de noviembre 2013. Obtenido de http://www.milenio.com/negocios/Cierran-maquiladoras-anos-LibreComercio_0_189581052.html

Arvanitis, S., Kubli, U. y Wörter, M. (2005). "Determinants of knowledge and technology transfer activities between firms and science institutions in Switzerland: an analysis based on firm data”. KOF-Arbeitspapiere/Working Papers 116, December. Swiss Federal Institute of Technology Zurich (ETHZ). http://dx.doi.org/10.2139/ssrn.892575.

Bevir, M \& Rhodes, R. (2006). “Governance Stories”. Public Administration 84 (4): 1085-1114. Blackwell Publishing Ltd. Oxford, USA.

Cárdenas, H. (2007). México y China en la cadena hilo-textil-confección en el mercado de Estados Unidos. Comercio exterior volumen 57, núm. 7. Julio de $2007 . \quad$ Obtenido de http://revistas.bancomext.gob.mx/rce/magazines/105/1/Cardenas-Dussel.pdf Casalet, M. (2005). "Los cambios en el diseño institucional y la construcción de redes de modernización tecnológica”. En Cimoli, M. y Yoguel, M. (Comp.), Redes, Jerarquías y Dinámicas Productivas. Buenos Aires: FLACSO. OIT y Miño y Davila.

Centro de estudios de Competitividad del Instituto Tecnológico de México CEC-ITAM (2010). La industria Textil en México; diagnóstico, prospectiva y estrategia. Obtenido de http://cec.itam.mx/sites/default/files/textil.pdf.

Coriat, B. \& Weinstein, O. (2004). "National institutional frameworks, institutional complementarities and sectoral systems of innovation". En Malerba, F. (Ed.), Sectorial systems of innovation. London: Cambridge University Press.

Dahl, M \& Pedersen, C. (2003). Knowledge flows through informal contacts in industrial clusters: myths or realities? DRUID Working Papers 03-01, Dinamarca.

Diario Oficial de la Federación (2013). Plan Nacional de Desarrollo 20132018. Obtenido de http://www.dof.gob.mx/nota_detalle.php?\%20codigo=5299465\&fecha=20/0 5/2013 [2015, 19 de agosto]

Feldman, E. (2009). Cámara Nacional de la Industria del Vestido. CANAIVE, Delegación Aguas Calientes. Obtenido de http://www.canaiveags.org.mx/Docs/MEXICO.pdf

García, L.\& Sánchez, M. (2015). “Análisis de la industria textil en la región sur del estado de Hidalgo atendiendo a las problemáticas de desempeño y desplazamiento de sus productos”. Academia Journal 7 (4): 2034-2040. ISSN 1946-5361. 
Gobierno del Estado de Hidalgo, Plan de desarrollo del Estado de Hidalgo 2011-2016. Obtenido de http://sepladerym.hidalgo.gob.mx/PED/home.html Hall, P. \& Taylor, R. (1996). "Political Science and the three new institutionalisms”. Political Studies (44): 936- 957.

Hernández, R., Fernández, C., Baptista, P. (2014). Metodología de la Investigación. (6ed) . Estados Unidos. Mc. Graw Hill.

Instituto Nacional de Estadística, Geográfica e Informática (INEGI) (2009). Censos económicos 2009. Obtenido de http://www.inegi.org.mx/

(2013). La industria textil y del vestido 2013. Series estadísticas y sectoriales. Obtenido de http://www.inegi.org.mx/

(2014). Indicadores del sector manufacturero cifras durante marzo de 2014. Comunica INEGI. Obtenido de

http://www.inegi.org.mx/inegi/contenidos/espanol/prensa/boletines/boletin/c omunicados/indicadores\%20del\%20sector\%20manufacturero/2014/mayo/co munica.pdf

Kumar, A. \& Maiti, P. (2007). "Efficiency of Indian manufacturing firms: Textile industry as a case study”. International Journal of Business Economics, 6 (1): 71-88.

Lynn, L., Heinrich, C. y Hill, C. (2001). Improving Governance, Washington, Georgetown University Press.

Miwa, Y. \& Ramseyer, M. (2000). “Corporate governance in transitional economies: Lessons from the prewar Japanese cotton textile industry”. Journal of Legal Studies, 29 (1): 171-203

Patrick Le Galés. (2002). European Cities. Social Conflicts and Governance. ISSN. 978-0-19-925278-7. Oxford University Press

Perkmann \& Walsh, (2008). "How firm source knowledge from universities: partnering versus contracting”. En J Bessant and T Venables (Eds.). Creating wealth from knowledge: meeting the innovation challenge. Cheltenham: Edward Elgar.

Plan de Desarrollo Institucional. Universidad Autónoma del Estado de Hidalgo. UAEH (2011-2017). Obtenido de http://www.uaeh.edu.mx/adminyserv/gesuniv/div_vin/docs/mod_vin_uaeh_ 2.2.pdf

Plan de desarrollo Municipal. Tepeji del Río (2012-2016). Obtenido de http://wwwtepejidelriohidalgo.gob.mx/archivos_pdf/PlanMunicipaldeDesarr ollo2012-2016.pdf.

Ramírez Z. (2011). Algodón la nueva fiebre. CNN Expansión, México. Obtenido de http:/www.cnnexpansion.com/expansion/2011/09/14/algodnla-nueva-fiebre

Romano, P. \& Vinelli, A. (2001). “Quality management in a supply chain perspective: Strategic and operative choices in a textile-apparel network”. 
International Journal of Operations \& Production Management, 21 (4): 446460.

Stezano, F. (2007). Políticas de construcción de redes ciencia-industria. El caso de los Consorcios CONACYT de México. En: Propuestas Interpretativas para una economía basada en el conocimiento, 183-216. Buenos Aires, Argentina: Mino y Dávila.

SEDECO, (2014). Secretaría de Desarrollo Económico. Obtenido de www.sedeco.gob.mx

Unión Europea, (2001). Benchmarking industry science relations. The role of framework conditions. ENTERPRISE DG y Ministerio Federal de Economía y Trabajo de Austria. Final Report Unión Europea: Viena. 